\title{
Culinary SME's: Entrepreneurial Education Skill in Uncertainty Conditions
}

\author{
Widji Astuti Fajar Supanto Bambang Supriyadi \\ University Of Merdeka Malang
}

\begin{abstract}
This study aims to determine of entrepreneurial skills of culinary SMEs in Indonesia, from an entrepreneurial perspective. The research sample of 136 entrepreneurs was determined from the Slovin formula. The collecting data was a simple random sampling technique. Entrepreneurship education skills prove to be a powerful tool for analyzing entrepreneurial skills in culinary SMEs. The results showed that there is an empirical gap between the development of culinary SMEs through education and skills training that has been carried out by various parties with the entrepreneurial skills needed by entrepreneurs in facing situations of uncertainty. The most gap is not fulfilled managerial skills and leadership skills. The most gap is unfulfilled managerial and leadership skills. Managerial skill need is an organizational structure, if needed organizational structure was quickly changed. Leadership skills need is to make quick decisions under pressure and have a business vision. Our study offers a series of recommendations for policymakers and researchers.
\end{abstract}

DOI: $10.7176 / \mathrm{JEP} / 11-24-03$

Publication date: December $31^{\text {st }} 2020$

\section{Introduction}

Government policies show that it takes sides with SMEs. The government makes efforts and steps for the empowerment of SMEs (Fajar, 2012). Government policy in favor of SMEs is a very appropriate step in improving the national economy. SMEs are a pillar of the country's economy, only possible because government policies support the creation of conditions for SMEs. Central Bureau of Statistics Indonesia (BPS, 2018), shows Indonesia's economic growth according to business fields (2017): processing sector $=0.91 \%$, with GDP growth of 4.27 . This indicates that culinary SMEs have become new venture entrepreneurship. In detail, the GDP growth and household consumption are presented:

Table 1. Economic Growth in the Processing Sector (\%)

\begin{tabular}{|l|c|c|c|c|}
\hline Year & GDP Contributor & Growth Rate & Culinary Growth Rate & Hous ehold consumption expenditure \\
\hline 2017 & $7,6 \%$ & $4,46 \%$ & $13,76 \%$ & $5,07 \%$ \\
\hline 2016 & $5,2 \%$ & $3,28 \%$ & $7,53 \%$ & $5,03 \%$ \\
\hline
\end{tabular}

Resource: BPS, 2018

The Ministry of Cooperatives and SMEs carries out various activities for sustainability SMEs. Another thing, The Trading house is an activity that helps promote SMEs products. Various ways have been made to market SMEs products including holding SMEs products events, introducing SMEs products through cooperative ambassadors, and advertising on print or social media. Various parties have also attempted to preserve and SMEs by providing capital assistance, technology grants, technical skills training such as packaging, labeling, product development (Widji Astuti, 2007,2009; Dvouletý and Ivanna, 2019).

However, based on observations, it still does not affect, income increases unstably (Widji Astuti, et al., 2017, 2019), and it is not uncommon to even switch sectors between SMEs, for example from product fashion to culinary, because culinary is seen as more promising and does not require operational skills special. Persistence in the selected SME products is very weak, even though changing the sector of the product can confuse the target market (Widji Astuti, et al., 2019). At the time of the Covid-19 pandemic, in conditions of business uncertainty, many SMEs switched products, especially from fashion to culinary with information technology-based ordering systems. The conditions culinary businesses also changed course from cafe, restaurant, weddings catering businesses/birthdays/celebrations others changed to serve home-delivery. In the coming years with changes in consumer behavior in purchasing, awareness of the importance of safety, health and the environment makes culinary businesses in competitive and uncertain condition.

Based on these problems, it is suspected that various top-down SME empowerment, development, and training activities are the root of the problem. Thus the aim of this study: to evaluate entrepreneurship education skills from the perspective of culinary SMEs entrepreneurs.

\section{Literature Review}

2.1. Entrepreneur skills

The concept of entrepreneurship is multidisciplinary (Gartner, 1985). In 1965, Schumpeter saw entrepreneurs as 
individuals who take advantage of market opportunities. Peter Drucker (1970) believes that entrepreneurship is someone who risk-taking.In 1990, Hisrich argues that an entrepreneur is characterized as someone who is creative thinking and innovative, can organize social and economic mechanisms to turn resources and manage situations, accept risks and failures. Different argue, Bolton and Thompson (2000), an entrepreneur is someone who innovates and creates to build something from values that are recognized around perceived opportunities. Entrepreneurs need a variety of entrepreneurial skills to develop and manage a business to succeed (Phelan and Sharpley, 2012). The success of managing a business is a reflection of entrepreneurial performance which is the result of a combination of individual motivation, business knowledge, and management skills. Skills are a demonstration of knowledge through action (Wickham, 2006). This view, which has been widely cited, was developed by Morales et al. (2013) who consider skills as a key competency.

Entrepreneurial skills are one of the skills that enable entrepreneurs to work effectively in uncertain conditions (Folahan and Omoriyi, 2006). However, entrepreneurial skills are also recognized as an important indicator in responding to change and uncertainty (Deuchar, 2007; Gibb, 2002).

\subsection{Establishing an Entrepreneurial Educations Skills/EES}

Today, researchers consider entrepreneurial skills to have an important role in entrepreneurship and business success (Gibb, 1993; Kuratko and Hodgetts, 2001; Hisrich, 2005; Oosterbeeket et al., 2010; Timmons, 1994; Zimmerer, 2008). Likewise, Pardakhetchi and Shafizadeh, 2006 and Imani (2009) view skills as equally important for everyone who wants to be self-employed. However, entrepreneurship research lacks a consensus on what key skills entrepreneurs possess or need (Morales and Marquina, 2013; Chell, 2013; Pittaway and Cope, 2007).

The debate about the assumption entrepreneurs are formed (Shefsky, 1996) and the assumption entrepreneurs are born, which come from individuals who already have skills, entrepreneurial families, have entrepreneurial characteristics are not needed. Therefore, the concept of entrepreneurial skills can be learned and trained (Lichtenstein and Lyons, 2001; Kuratko,2005) even if a person doesn't have entrepreneurial skills to start a business (Lazear, 2004; 2005). Matlay and Partners (2002) dan Jamieson (1984) categorize entrepreneurship education in three different ways:1. Awareness Creation (Education about companies), 2. Education for companies (Preparation of prospective entrepreneurs for innovation); and 3. Education in the company (Growth and development training for established entrepreneurs).

Studies developing skills frameworks for entrepreneurs have produced a different focus of observation. Smith, Schallenkamp, and Eichholz, (2007), direct the development of four skill categories: technical, managerial, entrepreneurial personality skills, and entrepreneurial maturity skills. Mohammad Salman Shabbir (2016), in Pakistan, developed 5 categories of skills: technical, managerial, leadership, entrepreneurial personal skills, and personal maturity skills. These various views are presented in the following table:

Table 2. Entrepreneurial Education Skills

\begin{tabular}{|l|l|}
\hline \multicolumn{1}{|c|}{ Author } & Framework Mea sured Entrepreneurial Education Skills \\
\hline $\begin{array}{l}\text { Mohammad Salman Shabbir etal. } \\
\text { (2016) }\end{array}$ & $\begin{array}{l}\text { Tehnical skills, Managerial skills, leadership skills, } \\
\text { entrepreneurial personal skills, and personal ma turity } \\
\text { skills. }\end{array}$ \\
\hline Kucel and Vilalta-Bufi (2016) & $\begin{array}{l}\text { analytical thinking and ability to perform well under } \\
\text { pressure. }\end{array}$ \\
\hline Aldén et al. (2014) & logical thinking, verbal skills, and emotional stability. \\
\hline Backes-Gellner and Moog (2013) & $\begin{array}{l}\text { analytical skills, practical skills, financial and marketing } \\
\text { skills. }\end{array}$ \\
\hline $\begin{array}{l}\text { Smith, Schallenkamp and } \\
\text { Eichholz, (2007) }\end{array}$ & $\begin{array}{l}\text { Tehnical skills, Managerial skills, entrepreneurial } \\
\text { personality skills, and entrepreneurial maturity skills. }\end{array}$ \\
\hline
\end{tabular}

This study using the EES measurement as developed by Mohammad Salman Shabbir et al. (2016).

\section{Methods}

The research design is quantitative research. This research using descriptive model research is model research that tells the current problem-solving is based on readymade data to present, analyze, and interpret data. The object of research is the city of Malang because Malang City of megacities with 3 destinations: the city of education, industry, and tourism (Slogan: 'Tri Bina Cita'). Culinary is developed to support the realization of the dreams of the 'Tri Bina Cita'. The sample was 136 culinary entrepreneurs of SMEs who used the Slovin formula, techniques sampling is simple random sampling. The questionnaires consisted of 28 items split between five instruments that measured entrepreneurial education skills. Scale and measurement design used a Likert scale (strongly agree and strongly disagree). 


\section{Results}

\subsection{Form of Entrepreneurial Education Programs for SMEs}

Entrepreneurial education is presented in the form of training. All training programs were categorized twice: classical (e.g. technical guidance, FGD) and demonstration (e.g. workshop, presentation). When the data are explored variations between locations (e.g. Malang City, versus Malang District, versus Batu City), are no significant differences. Based on, education of the respondent proved that undergraduate education tends to be more dominated by a curiosity about entrepreneurship. Table 3. summarizes the results for the entire sample.

Table 3. Entrepreneurs Education

\begin{tabular}{|c|c|c|c|}
\hline Education & About Entr epreneurial & For Entrepreneurial & In Entr epreneurial \\
\hline Non Scholar & $52(38,24 \%)$ & $44(32,35 \%)$ & $54(4 \%)$ \\
\hline Undergraduate & $75(55,14 \%)$ & $57(41,91 \%)$ & $57(42 \%)$ \\
\hline Postgraduate & $9(6,62 \%)$ & $35(25,74 \%)$ & 0 \\
\hline
\end{tabular}

Based on table 3. The majority of EES among undergraduates is about entrepreneurship training (awareness creation). Furthermore, training to prepare a business and innovate (training for companies). The training that is rarely held is Growth and development training for established entrepreneurs (training in companies).

This indicates that employment is experiencing problems in the educated workforce class, especially in the undergraduate group. In the non-scholar group, realizing that they have no choice but to be entrepreneurial, they become job creators. Dominate training programs on how to grow and develop as an entrepreneur as well as how to be creative. Different At the postgraduate level, entrepreneurship is dominant, because of pension or termination of employment. Thus, the majority of training programs are on how to be entrepreneurial and innovative. Meanwhile, the training program that has never been appreciated is the program to grow and develop a business. This is related to the level of education he has achieved. At the postgraduate level, critical thinking, analytical thinking, and creative thinking have been formed, so they can quickly respond to changes. Conclusion of data table 3. Culinary SME entrepreneurs need a lot of training programs on how to prepare entrepreneurs and innovations (Training For Companies). Meaning, the forms of 'for companies' training programs in developing entrepreneurial education skills have so far remained at the periphery and the more traditional 'about entrepreneurial' form continues to dominate. As in table 4. It shows that the majority of training programs focus on technical topics $(33.82 \%)$ and capital assistance $(20.59 \%)$ while training programs for business innovation such as Business planning (8.82\%), Managerial and Organization (8,09\% and Leadership (7.35\%) were marginalized because less than $10 \%$ of this topic was organized as a training program.

Table 4. Training Programs

\begin{tabular}{|l|c|c|c|}
\hline \multicolumn{1}{|c|}{ Subject Focus } & Total & \% & Cumulative \\
\hline Entrepreneurship & 16 & 11,76 & 11,76 \\
\hline Technologi & 46 & 33,82 & 45,58 \\
\hline Finance & 28 & 20,59 & 66,17 \\
\hline Business Planing & 12 & 8,82 & 74,99 \\
\hline SME Consultancy & 13 & 9,56 & 84,55 \\
\hline Leadership & 10 & 7,35 & 91,91 \\
\hline Mhnagement \& Organization & 11 & 8,09 & $\mathbf{1 0 0}$ \\
\hline TOTAL & $\mathbf{1 3 6}$ & $\mathbf{1 0 0}$ & \\
\hline
\end{tabular}

Validity and Reliability Test

Table 5. Validity Test

\begin{tabular}{|c|c|c|c|c|c|c|c|}
\hline Items & Coeff. & $\mathbf{r}_{\text {abd }}$ & Remarks & Items & Coeff. & $\mathbf{r}_{\text {tabel }}$ & Remarks \\
\hline 1 & 0,473 & 0,3739 & Valid & 15 & 0,438 & 0,3739 & Valid \\
\hline 2 & 0,577 & 0,3739 & Valid & 16 & 0,527 & 0,3739 & Valid \\
\hline 3 & 0,516 & 0,3739 & Valid & 17 & 0,448 & 0,3739 & Valid \\
\hline 4 & 0,463 & 0,3739 & Valid & 18 & 0,482 & 0,3739 & Valid \\
\hline 5 & 0,598 & 0,3739 & Valid & 19 & 0,583 & 0,3739 & Valid \\
\hline 6 & 0,425 & 0,3739 & Valid & 20 & 0,493 & 0,3739 & Valid \\
\hline 7 & 0,400 & 0,3739 & Valid & 21 & 0,465 & 0,3739 & Valid \\
\hline 8 & 0,441 & 0,3739 & Valid & 22 & 0,452 & 0,3739 & Valid \\
\hline 9 & 0,455 & 0,3739 & Valid & 23 & 0,435 & 0,3739 & Valid \\
\hline 10 & 0,534 & 0,3739 & Valid & 24 & 0,421 & 0,3739 & Valid \\
\hline 11 & 0,488 & 0,3739 & Valid & 25 & 0,550 & 0,3739 & Valid \\
\hline 12 & 0,481 & 0,3739 & Valid & 26 & 0,435 & 0,3739 & Valid \\
\hline 13 & 0,527 & 0,3739 & Valid & 27 & 0,582 & 0,3739 & Valid \\
\hline 14 & 0,478 & 0,3739 & Valid & 28 & 0,437 & 0,3739 & Valid \\
\hline
\end{tabular}


All items are valid, the corrected item-total correlation coefficient $>r_{\text {table }}$ at a probability of $0.05(0.3739)$

Table 6. Reliability Test

\begin{tabular}{|l|c|c|c|}
\hline \multicolumn{1}{|c|}{ Descriptions } & Apha Chronbach & Cut-off & Remarks \\
\hline Tehnical Skills & 0,898 & 0,60 & Reliable \\
\hline Managerial Skills & 0,857 & 0,60 & Reliable \\
\hline Leadership Skills & 0,869 & 0,60 & Reliable \\
\hline MaturityPersonal Skills & 0,911 & 0,60 & Reliable \\
\hline Personal Entrepreneurial Skills & 0,881 & 0,60 & Reliable \\
\hline
\end{tabular}

Table 6 , all values obtained $>$ cut-off $(0.6)$ is reliable.

\subsection{Entrepreneurial Education Skills}

The results showed that all respondents agreed on the statement items informing each entrepreneurial skill. Also supports the opinion of Sabhir (2019), that Entrepreneurial Education Skills are technical, managerial, leadership, personal maturity skills, and personal entrepreneurial skills.

Table 7. Entrepreneurial Education Skills

\begin{tabular}{|c|c|c|c|c|c|c|c|c|c|c|c|c|}
\hline \multicolumn{10}{|l|}{ TECHNICAL SKILLS } & \multicolumn{3}{|c|}{4,1891} \\
\hline \multirow[t]{2}{*}{ Discription } & \multicolumn{2}{|c|}{1} & \multicolumn{2}{|r|}{2} & \multicolumn{2}{|r|}{3} & \multicolumn{2}{|r|}{4} & \multicolumn{2}{|r|}{5} & \multirow[t]{2}{*}{ Mean } & \multirow{2}{*}{$\begin{array}{c}\text { Remark } \\
s\end{array}$} \\
\hline & $\Sigma$ & $9 \%$ & $\mathbf{\Sigma}$ & $9 \%$ & $\mathbf{\Sigma}$ & $9 \%$ & $\Sigma$ & $9 \%$ & $\mathbf{E}$ & $9 \%$ & & \\
\hline Produce different products & & & & & 9 & 6,6176 & 66 & 48,5294 & 61 & 44,85294 & 4,3824 & Agree \\
\hline Understand the services required & & & & & - & - & 66 & 48,5294 & 70 & 51,47059 & 4,5147 & Agree \\
\hline Have a guarantee of supply of raw materials & & & & & 13 & 9,5588 & 70 & 51,4706 & 53 & 38,97059 & 4,2941 & Agree \\
\hline Build a network & & & & & 31 & 22,794 & 61 & 44,8529 & 44 & 32,35294 & 4,0956 & Agree \\
\hline Able to a lign production and supply needs & & & & & 13 & 9,5588 & 88 & 64,7059 & 35 & 25,73529 & 4,1618 & Agree \\
\hline Able to a dapt technology & & & & & 26 & 19,118 & 79 & 58,0882 & 31 & 22,7941 & 4,0368 & Agree \\
\hline Able to meet the needs of technological equipment & & & & & 35 & 25,735 & 88 & 64,7059 & 13 & 9,5588 & 3,8383 & Agree \\
\hline \multicolumn{7}{|l|}{ MANAGERIAL SKILLS } & \multicolumn{6}{|c|}{3,9019} \\
\hline \multirow[t]{2}{*}{ Discription } & \multicolumn{2}{|c|}{1} & \multicolumn{2}{|r|}{2} & \multicolumn{2}{|r|}{3} & \multicolumn{2}{|r|}{4} & \multicolumn{2}{|r|}{5} & Mean & \multirow[t]{2}{*}{ Remarks } \\
\hline & $\mathbf{E}$ & $9 \%$ & \multicolumn{2}{|r|}{$9 \%$} & $\mathbf{\Sigma}$ & $9 \%$ & $\Sigma$ & $9 \%$ & $\mathbf{E}$ & 96 & & \\
\hline $\begin{array}{l}\text { If needed, the organizational structure was quickly } \\
\text { changed }\end{array}$ & & & & & 61 & 44,853 & 57 & 41,9118 & 18 & 13,2353 & 3,6838 & Agree \\
\hline Manage finances based on priorities and business needs & & & & & 39 & 28,676 & 79 & 58,0882 & 18 & 13,2353 & 3,8456 & Agree \\
\hline The final decision is taken by developing alternative & & & & & 9 & 6,6176 & 101 & 74,2647 & 26 & 19,1177 & 4,125 & Agree \\
\hline Mhke quick decisions under pressure & & & 4 & 2,941 & 44 & 32,353 & 75 & 55,1471 & 13 & 9,55882 & 3,7132 & Agree \\
\hline Change methods when proven wrong & & & & & 39 & 28,676 & 57 & 41,9118 & 40 & 29,4118 & 4,0073 & Agree \\
\hline Guarantee the implementation of decisions taken & & & & & 17 & 12,5 & 97 & 71,3235 & 22 & 16,1765 & 4,0368 & Agree \\
\hline LEADERSHIP SKILLS & & & & & & & & & & & 4,1662 & \\
\hline Discription & & & & 2 & & 3 & & 4 & & 5 & Mean & Remarks \\
\hline & $\mathbf{\Sigma}$ & $\%$ & $\mathbf{\Sigma}$ & $9 \%$ & $\mathbf{z}$ & $\%$ & $\mathbf{\Sigma}$ & 96 & $\mathbf{z}$ & $9 \%$ & & \\
\hline Ensure that the business is directed & & & & & & 0 & 96 & 70,5882 & 40 & 29,4118 & 4,2941 & Agree \\
\hline Organizations with effective delegation of authority & & & & & 9 & 6,6176 & 70 & 51,4706 & 57 & 41,9118 & 4,3529 & Agree \\
\hline Have a business vision & & & & & 44 & 32,353 & 70 & 51,4706 & 22 & 16,1765 & 3,8382 & Agree \\
\hline $\begin{array}{l}\text { Encourage members of the organization to move } \\
\text { forward and develop together }\end{array}$ & & & & & 9 & 6,6176 & 92 & 67,6471 & 35 & 25,7353 & 4,1918 & Agree \\
\hline Take the initiative in each situation & & & & & 5 & 3,6765 & 105 & 77,2059 & 26 & 19,117 & 4,1544 & Agree \\
\hline MATURITY PERSONAL SKILLS & & & & & & & & & & & 4,3118 & \\
\hline Discription & & & & 2 & & 3 & & 4 & & 5 & Mean & Remarks \\
\hline & $\Sigma$ & $9 \%$ & $\mathbf{E}$ & $9 \%$ & $\mathbf{E}$ & $9 \%$ & $\Sigma$ & $9 \%$ & $\Sigma$ & $9 \%$ & & \\
\hline $\begin{array}{l}\text { Freeing org anizational members to develop w ays of } \\
\text { carrying out tasks }\end{array}$ & & & & & 4 & 2,9412 & 57 & 41,9118 & 75 & 55,1471 & 4,5221 & Agree \\
\hline Introducing, improving and innovating in culinary & & & & & 17 & 12,5 & 53 & 38,9706 & 66 & 48,5294 & 4,3603 & Agree \\
\hline Be able to reflect desires into action & & & & & 18 & 13,235 & 70 & 51,4706 & 48 & 35,2941 & 4,2206 & Agree \\
\hline Be able to take responsibility & & & & & 13 & 9,5588 & 75 & 55,1471 & 48 & 35,2941 & \begin{tabular}{|l|l|}
42574 \\
\end{tabular} & Agree \\
\hline Be able to solve problems & & & & & 13 & 9,5588 & 83 & 61,0294 & 40 & 29,4118 & 4,1985 & Agree \\
\hline PERSONAL ENTREPRENEURIAL SKILLS & & & & & & & & & & & 4,2147 & \\
\hline Discription & & & & 2 & & 3 & & 4 & & 5 & Mean & Remarls \\
\hline & $\mathbf{E}$ & 96 & $\mathbf{E}$ & $9 \%$ & $\mathbf{E}$ & $9 \%$ & $\Sigma$ & 96 & $\Sigma$ & $9 \%$ & & \\
\hline Manage emotional & & & & & 13 & 9,5588 & 97 & 71,3235 & 26 & 19,1177 & 4,0956 & Agree \\
\hline Provide creative solutions & & & & & 18 & 13,235 & 52 & 38,2353 & 66 & 48,5294 & 4,3529 & Agree \\
\hline Brave to act in achieving company goals & & & & & 35 & 25,735 & 70 & 51,4706 & 31 & 22,7941 & 3,9706 & Agree \\
\hline Holistic action is needed to achieve company goals & & & & & 4 & 2,9412 & 57 & 41,9118 & 75 & 55,1471 & 4,5221 & Agree \\
\hline Able to exploit talents into professional potential & & & & & 26 & 19,118 & 66 & 48,5294 & 44 & 32,3529 & 4,1324 & Agree \\
\hline
\end{tabular}

Based on the average results of each skill, the most appreciated is the maturity of personal skills $(4,3118)$ and entrepreneur personal skills $(4,2147)$. This means that culinary SME entrepreneurs understand and have the character of an entrepreneur that may have been owned before becoming an entrepreneur or because time travel has become an entrepreneur, has shaped his entrepreneurial character. EES that has been marginalized from the training program are managerial $(3,9019)$ and leadership skills $(4,1662)$. Especially the training program that can quickly adjust organizational structures if needed, manage decisions effectively when under pressure, and be able 
to change the mindset to run a business with a vision. While technical skills rank third out of 5 skills, this means that the EES program on technical skills $(4,1891)$ is still needed as novelties continue to grow and developing in the culinary business, but facing situations and competition that are rapidly changing, it is very important to develop managerial skills and leadership skills to ensure the continuity of the culinary business in any situation.

Technological skills. From the most skilled SME entrepreneurs, understand the services required, produce different products, have a guarantee of supply of raw materials, able to align production and supply needs, build a network, be able to adapt technology, and be able to meet the needs of Technological equipment is at its weakest. This is related to the capital that SMEs have to be able to own technological equipment. However, in limited capital owned by culinary entrepreneurs, SMEs strive for equipment technology with their modifications. These results support the research conclusion by Widji (2007, 2009), Nurulhasanah (2016), Dvouletý et al. (2020).

Managerial skills. The most needed skills to those already possessed are the organizational structure was quickly changed, make quick decisions under pressure, manage finances based on priorities and business needs, change methods when proven wrong, guarantee the implementation of decisions taken and the final decision is taken by developing an alternative. These findings illustrate the peculiarities of SMEs in Indonesia which do not have a standard organizational structure because they are all done alone or involve families and are weak in responding to changes due to the weakness in making effective decisions in changing situations. This makes culinary SMEs marginalized in the competition. John Vargo (2011), that planning and making decisions carefully and structured in an effective but responsive and courageous manner will control the business.

Leadership skills based on consecutive abilities: organizations with an effective delegation of authority, ensure that the business is directed, encourage members of the organization to move forward and develop together, take the initiative in each situation, and have a business vision. The business vision is the weakest skill. This gives an indication that so far UKM players have not been given guidance in building SMEs with long-term vision. Therefore, it is found that many business fields move around only following trends businesses, even though the business vision plays an important role in building a sustainable business. The findings of research support Konstantinos (2014), and John Vargo et al. (2011), that leaders who can inspire people with hope and direction in the situation at hand will make them able to survive.

Maturity personal skills of culinary UKM players, namely Freeing organizational members to develop ways of carrying out tasks, Introducing, improving and innovating in culinary, be able to take responsibility, be able to reflect desires into action and be able to solve problems. The weak ability to solve problems is the leverage for the weak persistence in mastering the field that is being worked on. So, training based on problem-solving very important as in research Kylikki (2015).

Personal Entrepreneurial skills: holistic action is needed to achieve company goals, provide creative solutions, able to exploit talents into professional potential, Manage emotional and very weak is brave to act in achieving company goals. Kylikki (2015), prove competency whereby the company can reduce resistance to changes that can hinder SMEs business renewal.

\section{Discussion}

Most of the entrepreneurship training surveyed in this study used a more traditional approach that focuses on knowledge accumulation. Only about one-third of training specifically tries to develop entrepreneurial skills. Overall data on the form of entrepreneurial education skills tends to show that the traditional form of entrepreneurialism continues to play a dominant role, not limited to location or educational level. In fact, to be entrepreneurial plays an important role in business continuity. Currently, EES development needs that have been fulfilled are entrepreneurial personal maturity and entrepreneurial personality. While the needs have not been met, namely managerial skills and leadership skills. Thus, future training programs for SMEs are directed at the form of managerial skills and leadership skills programs, especially in shaping organizational structures, being trained in decision making using various analytical methods, and developing a business vision so as not to stagnate. This opinion supports Kyllikki (2015), that up-grading educational and training systems by attitudes towards work training programs, and especially comprehensive job skills training required by SMEs to master various tasks and providing stronger support to entrepreneurs to improve the entrepreneurial conditions of SMEs and the business possibilities that exist in a changing situation.

\section{Conclusion}

In conclusion, entrepreneurship is mostly about risk, innovation, creative thinking. An entrepreneur is a person who creates and innovates something that is perceived as valuable, has market opportunities, and accepts risk and failure. Besides, the concept of entrepreneurial education skills varies from country to country as needed for business continuity during conditions of competition and uncertainty. Based on the framework of the EES dimensions developed by Sabbir (2016), the need for culinary SMEs skills education from the entrepreneur's perspective is managerial skills and leadership skills. Therefore, with these findings, we can conclude that to adapt to competition and uncertain situations, SME actors need technical skills to stimulate creativity and innovation as 
well as the effectiveness and efficiency of production operations. However, what is especially needed at this time is the mastery and ability to manage a business and lead a business by carrying out self-development through managerial and leadership skills education.

One of the limitations of this study is the lack of objective measures of entrepreneurial success caused by the entrepreneurial orientation and motivation of culinary SMEs entrepreneurs who have been given managerial and leadership skills education. Therefore, future research should examine entrepreneurial achievement to assess the validity of entrepreneurial predictions for SMEs mediated by entrepreneurial education skills. This measure can be in the form of an assessment of business performance, both financial and non-financial, such as revenue growth, customer growth, and market share. Finally, longitudinal studies will be useful in establishing the causal nature of these relationships.

The research results have theoretical and practical implications. Theoretically, it supports Shabbir's (2016) research in using the dimensions of entrepreneurial education skills and the conception of Shefsky, L. E. (1996) that entrepreneurs are not born but formed. On a practical level, the results show that the entrepreneurial personality or character exists in every human being and can be a useful tool to promote success as an entrepreneur. Importantly, this applies not only to business founders but also employees (company entrepreneurship) and people who work in fields not related to culinary business such as social (social entrepreneurship) and creative circles (discovery entrepreneurship). Organizations can benefit from the selection of self-employed individuals based on their personality profiles. Research shows that organizations that recruit and develop entrepreneurship can gain a competitive advantage in their respective markets (Lumpkin, 2007) and be a valuable tool for identifying such individuals, both for employee selection and retention, but also for other areas including minimizing the risk of start-up failure.

\section{Acknowledgment}

Research funding is from the Ministry of Research, Technology and Higher Education of the Republic of Indonesia.

\section{References}

Aldén, L., Hammarstedt, M., \& Neuman, E. (2014), All about balance? A test of the Jack-of-all-trades theory among the self-employed in Sweden, Working paper, Linnaeus Centre for Labour Market and Discrimination Studies. Repository, Sweden: Linnaeus University.

Backes-Gellner, U., \& Moog, P. (2013), The disposition to become an entrepreneur and the jacks-of-all-trades in social and human capital, The Journal of Socio-Economics, 47, p.55-72.

Bolton, W.K. and Thompson, J.L. (2000). Entrepreneurs: Talent, temperament, technique. ButterworthHeinemann, Oxford.

Chell, E. (2013). Review of skill and the entrepreneurial process. International Journal of Entrepreneurial Behaviour and Research, 19(1), p.6-31

Deuchar, R. 2007. Citizenship, enterprise and learning: Harmonising competing educational agendas, London, Trentham Books

Drucker, P. (1970). Entrepreneurship in business enterprise. Journal of Business Policy Vol.1 (1) Pp. 3-12.

Fajar Supanto (2012), Impact Evaluation of the Village / Kelurahan Potential Empowerment Program (P3DK) in East Java, repository, Bapemas Prov. Jatim.

Gartner, W.B. (1985). A framework for describing the phenomenon of new venture creation. Academy of Management Review, October, 10(4), p.696-706.

Gibb, A. 1993. The enterprise culture and education. International Small Business Journal.11(3):p.11-34 .2002. In pursuit of a new enterprise and entrepreneurship paradigm for learning, creative destruction, new values, new waysof doing things and new combinations of knowledge. International Journal of Management Reviews 4(3):p.213-31.

Giunipero, L.C., Denslow, D., Eltantawy, R. (2005), Purchasing/supply chain management flexibility: moving to an entrepreneurial skill set, Industrial Marketing Management, Vol. 34. No.6, p. 602-61

Hisrich, R.D. (1990). Entrepreneurship/ Intrapreneurship. AmPsychol, 45(2), p. 209-222.

Hisrisch, R.D., Peters, M.P., Shepherd, D.A. (2005). Entrepreneurship (6th ed.). New York: McGraw-Hill.

Imani, M.N., Azarakhsh, T., and Ashesghi, M.(2009). Entrepreneurship. (2rd ed). Tehran: Farhang-e-Sabz

Jamieson (1984), Schools and Enterprise. In Watts, A. \& Moran, P. (eds.) Education for enterprise. Cambridge: CRAC

John Vargo, Erica Seville, (2011), Crisis Strategic Planning for SMEs: Finding the Silver Lining. International Journal of Production Research - Creating Resilient SMEs, Vol49, Issue18, p. 5619-5635.

Konstantinos Bourletidis and Yiannis Triantafyllopoulos (2014) SMEs Survival in time of Crisis: Strategies, Tactics and Commercial Success Stories. Procedia - Social and Behavioral Sciences. 148, p. 639 - 644

Kucel, A., \& Vilalta-Bufi, M. (2016), Entrepreneurial skills and wage employment, International Journal of Manpower, 37(3), p. 556-588. 
Kuratko, D. F. andHodgetts, T. M. (2001). Entrepreneurship: A Contemporary Approach, 5rd edition. Fort Worth, TX: The Dryden Press.

Kuratko, D.F. (2005), 'The emergence of entrepreneurship education: Development, Trends and Challenges', Journal Entrepreneurship Theory and Practice, Vol.29(5), p.577-598.

Kyllikki Taipale-Erävala, (2015), Survival Competencies in SMEs in Changing Business Environments Repository, Abo Akademik University Turku Finlandia, Faculty of Science and Engineering, Industrial Management.

Lazear, E. P. (2004). Balanced skills and entrepreneurship. American Economic Review, p. 208-211

Lazear, E.P. (2005), Entrepreneurship, Journal of Labor Economics, 23(4), p.649-680.

Lichtenstein, G.A., and Lyons, T.S. (2001). The entrepreneurial development system: Transforming business talent and community economies. Economic Development Quarterly, 15(1), p.3-20

Mitchelmore, S. and Rowley, J. (2013), Entrepreneurial competencies of women entrepreneurs pursuingbusiness growth, Journal of Small Business and Enterprise Development, Vol. 20 No. 1,p. 125-142.

Morales, C., and Marquina, P.S. (2013). Entrepreneurial Skills, Significant Differences between Serbian and German Entrepreneurs. Journal of CENTRUM Cathedra: The Business and Economics Research Journal, 6(1).p.129-141

Nurulhasanah Abdul Rahman, Zulnaidi Yaacobb, RafisahMat Radzi (2016). An Overview of Technological Innovation on SME Survival: A Conceptual Paper. Procedia - Social and Behavioral Sciences 224, p.508 515

Oosterbeek, H., van Praag, M., andIjsselstein, A. (2010). The impact of entrepreneurship education on entrepreneurship skills and motivation. European Economic Review, 54(3), p. 442-454.

Dvouletý, Ondrej; and Ivana Blažková (2019). The Impact of Public Grants on Firm-Level Productivity: Findings from the Czech Food Industry . Sustainability, 11(2), 552; https://doi.org/10.3390/su11020552

Dvouletý, Ondrej; Stjepan Srhoj; Smaranda Pantea. (2020). Public SME grants and firm performance in EuropeanUnion: A systematic review of empirical evidence. Small Bus Economic. Januari 2020. DOI: 10.1007/s11187-019-00306-x

Pardakhtchi,M., and Shafizadeh,H.(2006). Introduction to Entrepreneurship Organization. (1rd ed) Tehran:Arasbaran

Phelan, C., andSharpley, R. (2012). Exploring entrepreneurial skills and competencies in farm tourism. Local Economy, 27(2), p.103-118.

Pittaway, L. and Cope, J., (2007), Entrepreneurship Education -A Systematic Review of the Evidence, International Small Business Journal, 25 (5), p.477-506.

Pittaway, L.; Cope, J. 2007. Simulating entrepreneurial learning. Management Learning, 38, p.211-233.

Salman, Mohammad Shabbir, Mohd Noor Mohd Shariff, Arfan Shahzad, (2016), Determinants of Entrepreneurial Skills set in Pakistan: A Pilot Study, International Journal of Academic Research in Accounting, Finance and Management Sciences, Vol. 6, No.2, p. 76-86

Schumpeter, J.A. (1965). Economic theory and entrepreneurship history. In Aitken, H.G (ed). Explorations in enterprise. Cambridge, MA: Harvard University Press.

Shefsky, L. E. (1996). Entrepreneurs are made not born. New York: McGraw-Hill

Smith, WL., Schallenkamp, K., and Eichholz, D.E. (2007).Entrepreneurial skills assessment: an exploratory study.International Journal of Management and Enterprise Development,4(2), p.179-201.

Timmons, J. A. (1994). New venture creation: Entrepreneurship for the 21st century (4th ed.). Burr Ridge, IL: Irwin Press.

Wickham, P.A. (2006). Strategic entrepreneurship (4th ed.). London: Pearson Education.

Widji, Astuti (2019), Entrepreneurial Skills and SME's Business Performance: Empirical Study Culinary Business, Journal of Economics and Sustainable Development, Vol. 10, No. 22, p. 160-166

Widji Astuti, Iwan, Kurniawan S.; Tjahyo S; (2017), The influence of market orientation, learning orientation, and entrepreneurial orientation toward innovation and impact on company performance, International Journal of Multidisciplinary Research and Development, Vol. 4 (9), p. 73-82

Widji, Astuti; (2009); Analysis of Empowerment of Small Industries through Training and Grants of Coconut Fiber Separator Technology for Coconut Fiber Craftsmen Group in Dati II Malang Regency Tulungagung; Repository; Bappeda Prop. Jatim.

Widji, Astuti (2007), Theoretical Study of the Concept of Business Independence in Relation to Providing Small Business Capital Assistance for the Informal Sector in Malang City, Repository,Unmer Malang

Zimmerer, T.W. and Scarborough, N.M. 2008. Essentials of entrepreneurship and small business management. 5rd ed. New Jersey: Prentice Hall 